\title{
Penggunaan Biokompos dalam Bioremediasi Lahan Tercemar Limbah Minyak Bumi
}

\author{
Barokah Aliyanta ${ }^{1}$, La Ode Sumarlin ${ }^{2}$, Ahmad Saepul Mujab ${ }^{2}$ \\ ${ }^{1)}$ Pusat Aplikasi Teknologi Isotop dan Radiasi Badan Tenaga Nuklir Nasional \\ Pasar Jum'at Jakarta Selatan \\ ${ }^{2}$ Program Studi Kimia Fakultas Sains dan Teknologi UIN Syarif Hidayatullah Jakarta \\ Jalan Ir. H. Juanda No 95 Ciputat Tangerang Selatan \\ e-mail : barokahaliyanta@yahoo.com
}

\begin{abstract}
Abstrak
Penelitian ini dilakukan untuk mengetahui efektifitas biokompos, rumput gajah dan kelompok mikroba yang efektif dalam bioremediasi lahan tercemar minyak bumi yang dilakukan dalam skala laboratorium, dan bahan tambahan yang digunakan urea sebagai sumber nitrogen. Pada penelitian ini dilakukan berdasarkan rasio $\mathrm{C} / \mathrm{N}$ yaitu 15,10 , dan 5. Parameter uji yang dilakukan untuk mengetahui kondisi optimal yang dicapai pada remediasi terdiri atas $\mathrm{pH}$, kadar air, kadar abu, dan kemampuan ikat air/water holding capacity (WHC). Hasilnya menunjukan degradasi TPH (Total Petroleum Hidrokarbon) sebesar 91,15\% dengan komposisi medium (100 g berat kering lumpur minyak bumi, $100 \mathrm{~g}$ berat kering biokompos, $9 \mathrm{~g}$ urea, rasio $\mathrm{C} / \mathrm{N}=5$ ) menggunakan perlakuan dari kombinasi rumput gajah, mikroorganisme, urea dan biokompos selama 35 hari. Faktor lingkungan yang menghasilkan kondisi optimal ini dicapai pada remediasi diperoleh melalui kondisi awal $\mathrm{pH}$ 8,25; kadar air 49,97\%; WHC 101,64\%; dan kadar abu 63,76\% dan kondisi akhir pH 6,25; kadar air 55,04\%; kadar abu 73,39\%; dan WHC 124,11\%. Penambahan kompos dan urea dapat meningkatkan efisiensi degradasi TPH dan diperoleh hubungan positif antara jumlah penambahan kompos dan urea terhadap tingkat degradasi TPH.
\end{abstract}

Kata kunci : biokompos, bioremediasi, degradasi, WHC, TPH

\begin{abstract}
This research was conducted to determine the effectiveness of biocompost and elephant grass of rehabilitating oil polluted land using landfarming methods, in combination with the addition of urea as sources of nitrogen. This research was conducted based on the 15,10 , and 5 of $\mathrm{C} / \mathrm{N}$ ratios, respectively. Test parameters needed to knowing the optimal condition in remediation were $\mathrm{pH}$, water content, ash content, and water holding capacity (WHC). Results show the Total Petroleum Hydrocarbon (TPH) was degraded until 91,15\% for 35 days. Under treatment of elephant grass, urea, biocompost combination within composition medium of (100 g dry mass soil polluted hydrocarbon, $100 \mathrm{~g}$ dry mass biocompost, $9 \mathrm{~g}$ fertilizer, and $\mathrm{C} / \mathrm{N}$ ratio : 5) using combined treatment of elephant grass, microorganisme, fertilizer, and biocompost after 35 days. The environmental factor yielding this optimal remediation reached was obtained through initial condition of $\mathrm{pH} 8,25$; water content 49,97\%; WHC 101,64\%; ash content $63,76 \%$ and final condition of $\mathrm{pH}$ 6,25; water content 55,04\%; ash content 73,39\%; and WHC 124,11\%, respectively. The addition of compost and urea has increased the efficiency of TPH degradation and obtained positive relationship between addition amounts of compost and urea to the level of TPH degradation.
\end{abstract}

Key words: biocompost, bioremediation, degradation, WHC, TPH

\section{PENDAHULUAN}

Limbah minyak bumi dapat terjadi di semua lini aktivitas perminyakan mulai dari eksplorasi sampai ke proses pengilangan dan berpotensi menghasilkan limbah berupa lumpur minyak bumi (Oily Sludge). Salah satu kontaminan minyak bumi yang sulit diurai adalah senyawaan hidrokarbon. Ketika senyawa tersebut mencemari permukaan tanah, maka zat tersebut dapat menguap, tersapu air hujan, atau masuk ke dalam tanah kemudian 
terendap sebagai zat beracun. Akibatnya, ekosistem dan siklus air juga ikut terganggu (Karwati, 2009).

Secara alamiah lingkungan memiliki kemampuan untuk mendegradasi senyawasenyawa pencemar yang masuk ke dalamnya melalui proses biologis dan kimiawi. Namun, sering kali beban pencemaran di lingkungan lebih besar dibandingkan dengan kecepatan proses degradasi zat pencemar tersebut secara alami. Akibatnya, zat pencemar akan terakumulasi sehingga dibutuhkan campur tangan manusia dengan teknologi yang ada untuk mengatasi pencemaran tersebut (Nugroho, 2006).

Selain itu, Atlas (1981) dalam Nugroho (2006) juga menjelaskan bahwa banyak senyawa-senyawa organik yang terbentuk di alam dapat didegradasi oleh mikroorganisme bila kondisi lingkungan menunjang proses degradasi, sehingga pencemaran lingkungan oleh polutan-polutan organik tersebut dapat dengan sendirinya dipulihkan. Namun pada beberapa lokasi terdapat senyawa organik alami yang resisten terhadap biodegradasi sehingga senyawa tersebut akan terakumulasi di dalam tanah.

Penanggulangan pencemaran minyak dapat dilakukan secara fisik, kimia dan biologi. Penanggulangan secara fisik umumnya digunakan pada langkah awal penanganan, terutama apabila minyak belum tersebar ke mana-mana. Namun cara fisika memerlukan biaya yang sangat tinggi untuk pengangkutan dan pengadaan energi guna membakar materi yang tercemar. Penanggulangan secara kimia dapat dilakukan dengan bahan kimia yang mempunyai kemampuan mendispersi minyak, sehingga minyak tersebut dapat terdispersi. Terutama ketika zat pencemar tersebut dalam konsentrasi tinggi. Namun cara ini memiliki kelemahan, yaitu mahal pengoprasiannya karena memakan biaya yang cukup besar dan metode kimia memerlukan teknologi dan peralatan canggih untuk menarik kembali bahan kimia dari lingkungan agar tidak menimbulkan dampak negatif yang lain. Mengingat dampak pencemaran minyak bumi baik dalam konsentrasi rendah maupun tinggi cukup serius, maka manusia terus berusaha mencari teknologi yang paling mudah, murah dan tidak menimbulkan dampak lanjutan (Nugroho, 2006).
Salah satu alternatif penanggulangan lingkungan tercemar minyak adalah dengan teknik bioremediasi, yaitu suatu teknologi yang ramah lingkungan, efektif dan ekonomis dengan memanfaatkan aktivitas mikroba seperti bakteri. Melalui teknnologi ini diharapkan dapat mereduksi minyak buangan yang ada dan mendapatkan produk samping dari aktivitas tersebut (Udiharto et al.,1995). Bioremediasi merupakan salah satu teknologi inovatif untuk mengolah kontaminan, yaitu dengan memanfaatkan mikroba, tanaman, enzim tanaman atau enzim mikroba (Gunalan, 1996).

Sebelumnya telah dilakukan penelitian oleh Tang., et al (2010) tentang bioremediasi pada tanah yang tercemar minyak menggunakan kombinasi tanaman ryegrass dan kelompok mikroba yang efektif dilakukan dengan "pot experiment". Hasilnya menunjukkan degradasi sebesar $58 \%$ menggunakan perlakuan dari kombinasi tanaman dan mikroorganisme setelah 162 hari dengan meningkatkan nilai degradasi total hidrokarbon minyak (THM/TPH) sebesar 17\% dibandingkan kontrol.

Pada penelitian ini diharapkan hasil degradasi Total Petroleum Hidrokarbon (TPH) lebih besar dari pada penelitian diatas. Penelitian ini akan dikaji proses bioremediasi limbah lumpur minyak bumi dengan biokompos menggunakan teknik landfarming pada skala laboratorium. Teknik landfarming adalah teknik bioremediasi ex situ yang memanfaatkan tanah sebagai media dan menanami tanaman. Salah satu tanaman yang digunakan adalah rumput gajah. Rumput gajah (Pennisetum purpureum Schumacher) adalah tanaman yang dapat tumbuh di daerah dengan minimal nutrisi. Rumput gajah membutuhkan minimal atau tanpa tambahan nutrisi. Tanaman ini mampu beradaptasi terhadap polutan dengan konsentrasi tinggi dan dapat juga memperbaiki kondisi tanah yang rusak akibat erosi. Tanaman ini juga dapat hidup pada tanah kritis dimana tanaman lain relatif tidak dapat tumbuh dengan baik (Sanderson dan Paul, 2008 dalam Ambriyanto, 2010).

Selama penelitian dilakukan pengamatan pada pengaruh faktor-faktor lingkungan seperti $\mathrm{pH}$, kemampuan ikat air, kadar air, kadar abu, TPH (Total Petroleum Hidrokarbon), dan biomassa rumput gajah. 
Diharapkan penelitian ini adalah untuk mengetahui kemampuan biokompos dalam menurunkan kadar TPH (Total Petroleum Hidrokarbon) tanah yang tercemar minyak bumi, dan Mendapatkan faktor-faktor lingkungan yang optimal, yaitu $\mathrm{pH}$, kemampuan ikat air, kadar air, kadar abu, serta TPH dengan teknik landfarming.

\section{METODE PENELITIAN}

\section{Bahan dan Alat}

Bahan yang digunakan dalam penelitian ini adalah vermikompos steril, n-heksan, rumput gajah, limbah lumpur minyak bumi yang didapatkan dari pertambangan tradisional Cepu Jawa Timur. Sedangkan alat-alat yang digunakan adalah Oven listrik, tanur, cawan petri, desikator, neraca analitik, pot plastik, $\mathrm{pH}$ indikator, ketas saring, Erlenmeyer dan peralatan gelas lainnya.

\section{Cara Kerja}

Penelitian yang dilakukan adalah uji biodegradasi hidrokarbon minyak bumi dengan media uji pot menggunakan Rancangan Acak Lengkap dan perlakuan dilakukan berdasarkan perbedaan rasio $\mathrm{C} / \mathrm{N}$ yaitu 15 dengan simbol A, 10 dengan simbol $\mathrm{B}$, dan 5 dengan simbol C. Perlakuan yang dilakukan ada yang diberi inokulan dan tanpa inokulan selama 35 hari. Kemudian sampel dikode dengan huruf A, B, dan C. Setiap sampel A, B, dan C dilakukan pengulangan empat kali, sampel A tanpa inokulan dikode dengan A11, A12, A13, dan 14, dengan inokulan dikode dengan A21, A22, A23, dan A24. Pada sampel B tanpa inokulan dikode dengan B11, B12, B13, dan B14, untuk dengan inokulan dikode dengan B21, B22, B23, dan B24. Sedangkan untuk sampel C tanpa inokulan dikode dengan $\mathrm{C} 11, \mathrm{C} 12, \mathrm{C} 13$, dan $\mathrm{C} 14$, dan sampel dengan inokulan dikode dengan C21, C22, C23, dan C24. Semua sampel dianalisis pada awal dan akhir perlakuan. Sebelum sampel dimasukkan ke dalam media pot, dianalisis terlebih dahulu secara duplo.

\section{Pembuatan Media Dalam Pot}

Sebanyak $100 \mathrm{~g}$ berat kering kompos tambah inokulan sebesar $5 \mathrm{~g}$ yang dinamakan biokompos. Kemudian disisihkan sebagian 432 untuk poting, lalu dicampurkan dengan lumpur minyak bumi yang sebelumnya sudah ditambahkan urea sesuai rasio $\mathrm{C} / \mathrm{N}$ yang digunakan, diaduk hingga merata, selanjutnya dimasukan dalam pot. Cara memasukan media dalam pot seperti gambar berikut :

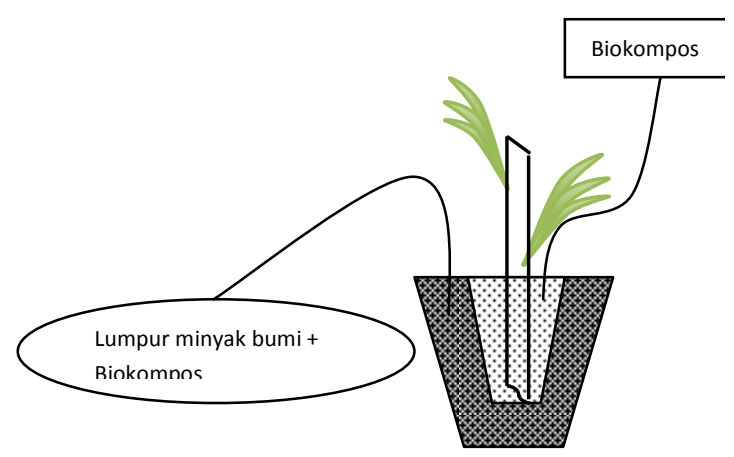

Gambar 1. Media Uji Pot

Tabel 1. Perlakuan yang dilakukan dalam penelitian

\begin{tabular}{|c|c|c|c|c|c|}
\hline \multirow{2}{*}{ Kode } & \multicolumn{5}{|c|}{ Komposisi } \\
\cline { 2 - 6 } & $\begin{array}{c}\text { Lumpur } \\
\text { minyak } \\
\text { bumi (g) }\end{array}$ & $\begin{array}{c}\text { Biokomp } \\
\text { os (g) }\end{array}$ & $\begin{array}{c}\text { Urea } \\
(\mathrm{g})\end{array}$ & $\begin{array}{c}\text { Inokulu } \\
\mathrm{m}\end{array}$ & $\mathrm{C} / \mathrm{N}$ \\
\hline A11 & 200 & - & - & - & 15 \\
\hline A12 & 200 & - & - & - & 15 \\
\hline A13 & 200 & - & - & - & 15 \\
\hline A14 & 200 & - & - & - & 15 \\
\hline A21 & 200 & - & - & + & 15 \\
\hline A22 & 200 & - & - & + & 15 \\
\hline A23 & 200 & - & - & + & 15 \\
\hline A24 & 200 & - & - & + & 15 \\
\hline B11 & 100 & 100 & 2 & - & 10 \\
\hline B12 & 100 & 100 & 2 & - & 10 \\
\hline B13 & 100 & 100 & 2 & - & 10 \\
\hline B14 & 100 & 100 & 2 & - & 10 \\
\hline B21 & 100 & 100 & 2 & + & 10 \\
\hline B22 & 100 & 100 & 2 & + & 10 \\
\hline B23 & 100 & 100 & 2 & + & 10 \\
\hline B24 & 100 & 100 & 2 & + & 10 \\
\hline C11 & 100 & 100 & 9 & - & 5 \\
\hline C12 & 100 & 100 & 9 & - & 5 \\
\hline C13 & 100 & 100 & 9 & - & 5 \\
\hline C14 & 100 & 100 & 9 & - & 5 \\
\hline C21 & 100 & 100 & 9 & + & 5 \\
\hline C22 & 100 & 100 & 9 & + & 5 \\
\hline C23 & 100 & 100 & 9 & + & 5 \\
\hline C24 & 100 & 100 & 9 & + & 5 \\
\hline
\end{tabular}

Keterangan : - (tanpa inokulan, tanpa urea, dan tanpa kompos) dan + (ditambah inokulan)

Catatan : walaupun tanpa inokulan, perlakuan tersebut mengandung bakteri pendegradasi minyak bumi yang dapat terinduksi pertumbuhannya dengan mengoptimasikan kondisi lingkungannya, dalam hal ini medium bagi pertumbuhan.

\section{Pengukuran kadar pH}

5 g sampel A, B, dan C ditimbang, kemudian ditambah aquades $25 \mathrm{ml}$ dengan 
perbandingan 1:5. Dikocok dengan mesin kocok selama 30 menit, didiamkan selama 10 menit, lalu diukur dengan kertas lakmus (SEAMEO BIOTROP, 2011).

\section{Kadar air}

Cawan dioven selama 1 jam, lalu dikeringanginkan dalam desikator selama 30 menit. Diambil 5 gram masing-masing sampel A, B, dan C, dimasukkan ke dalam cawan lalu ditimbang, kemudian dikeringkan di dalam oven dengan suhu $65-105^{\circ} \mathrm{C}$ selama $24-72$ jam. Setelah sampel kering dengan berat yang tetap, kemudian ditimbang. Kadar air dihitung berdasarkan persamaan (Natural Resources Conservation Service, 2000):

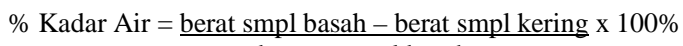
berat sampel basah

\section{Kadar abu}

Sampel dan kompos A, B, dan C yang sudah diketahui kadar airnya, lalu diabukan dalam tanur pada suhu $650^{\circ} \mathrm{C}$ selama 12 jam. Dihitung kadar abu dari media kering berdasarkan persamaan (Zyomuya, 2005):

$\%$ Kadar abu $=\frac{\text { berat abu }}{\text { berat kering }} \times 100 \%$

\section{Kemampuan ikat air/ Water Holding Capacity (WHC)}

Sampel basah yang sudah diketahui terlebih dulu kadar airnya dianggap sebagai berat awal $\left(\mathrm{W}_{0}\right)$ dan kemudian ditempatkan dalam beker. Kemudian sampel direndam dengan aquades selama 1-2 hari dan disaring menggunakan kertas whatman, sampel jenuh dianggap sebagai berat jenuh $\left(\mathrm{W}_{\mathrm{s}}\right)$, kadar air sebagai MC, jumlah air yang tertahan oleh sampel dihitung sebagai WHC menurut persamaan (Ahn et al., 2009):

$$
W H C=\frac{\left\{\left(W_{s}-W_{0}\right)+M C \times W_{0}\right\}}{\left\{(1-M C) \times W_{0}\right\}}
$$

\section{Total Petroleum Hidrokarbon (TPH)}

$10 \mathrm{~g}$ sampel ditambah $50 \mathrm{ml}$ n-heksana dalam Erlenmeyer $250 \mathrm{ml}$. Kemudian dishaker sampai terlihat minyaknya keluar dari sampel, lalu ditransfer kedalam beaker glas yang sudah diketahui bobotnya. Kemudian di uapkan dalam oven pada suhu $70{ }^{\circ} \mathrm{C}$, Minyak yang diperoleh lalu ditimbang untuk mengetahui jumlah minyak yang terkandung dalam contoh sampel setelah ekstraktannya habis menguap (Ijah \& Upke 1992 dalam Ijah et al. 2008). Tingkat degradasi diukur dengan rumus sebagai berikut:

$$
\% \text { Degradasi }=\frac{T P H_{0}-T P H_{35}}{T P H_{0}} \times 100 \%
$$

$\mathrm{TPH}_{0}=\mathrm{TPH}$ hari ke- $0(\mathrm{~g})$

$\mathrm{TPH}_{n}=\mathrm{TPH}$ hari ke-35(g)

\section{HASIL DAN PEMBAHASAN}

\section{pH}

Hasil penelitian menunjukan bahwa pada keadaan awal $\mathrm{pH}$ masih berkisaran 7,258,25 (Gambar 2). Hal ini sesuai dengan $\mathrm{pH}$ optimum karena menurut Nghia (2007) $\mathrm{pH}$ optimum untuk biodegradasi berada kisaran antara 6 dan 8. Namun setelah diberi perlakuan, $\mathrm{pH}$ mengalami perubahan penurunan nilai $\mathrm{pH}$ yang menunjukan bahwa mikroorganisme beraktivitas. Kebanyakan bakteri tumbuh pada $\mathrm{pH}$ netral atau sedikit alkali. $\mathrm{pH}$ berpengaruh pada fungsi seluler mikroorganisme, transport membran, dan keseimbangan reaksi (Cookson, 1990 dalam Sugoro, 2002).

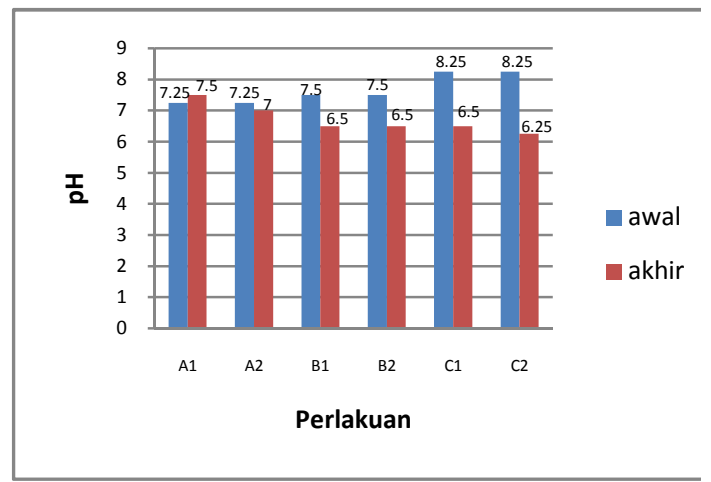

Gambar 2. Hasil Analisa $\mathrm{pH}$

Berdasarkan hasil analisis, pada umumnya semua perlakuan mengalami penurunan nilai $\mathrm{pH}$. Penurunan nilai $\mathrm{pH}$ tersebut diduga disebabkan oleh aktivitas konsorsium bakteri yang membentuk metabolit-metabolit asam. Biodegradasi alkana yang terdapat dalam 
minyak bumi akan membentuk alkohol dan selanjutnya menjadi asam lemak. Asam lemak hasil degradasi alkana akan dioksidasi lebih lanjut membentuk asam asetat dan asam propionat (Gambar 3), sehingga dapat menurunkan nilai $\mathrm{pH}$ medium (Rosenberg, E., Legmann,R., Kushmaro, A., Taube, R., dan Ron, E.Z. 1992 dalam Nugroho, 2006).

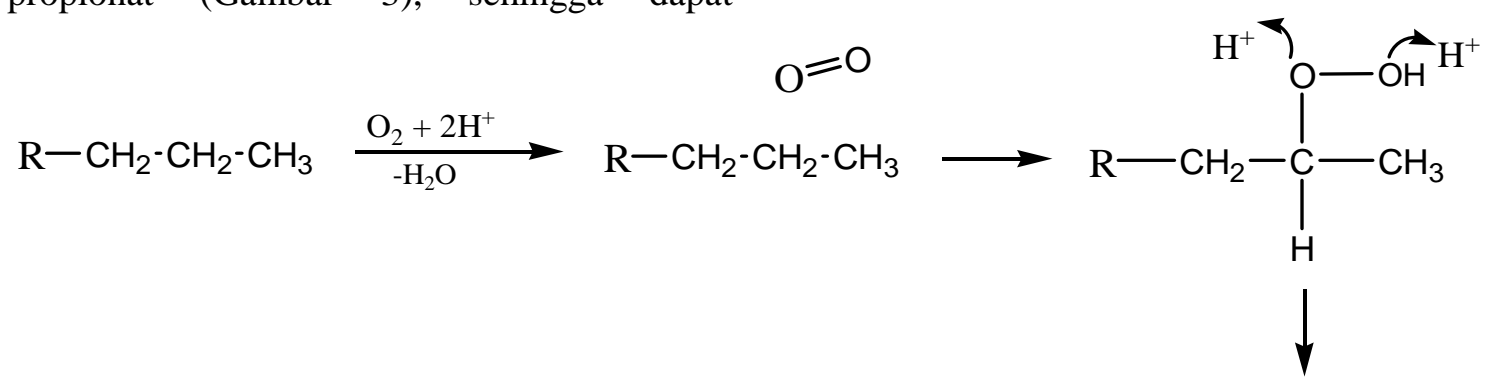

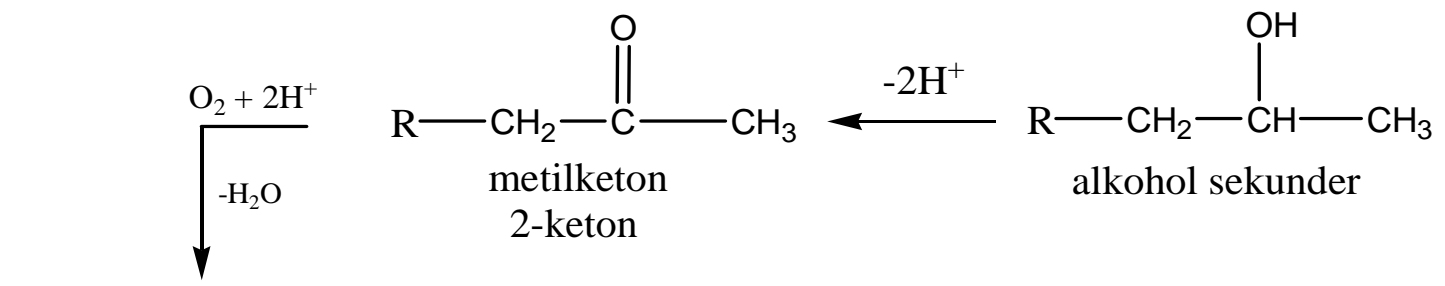<smiles>[R]COC(C)=O</smiles>
$\underset{\text { aldehid }}{\stackrel{\downarrow^{-2}}{\mathrm{CHO}}} \stackrel{-\mathrm{H}_{2} \mathrm{O}}{-2 \mathrm{H}^{+}} \underset{\downarrow}{\mathrm{R}}-\mathrm{COOH}$

Siklus Krebs

Gambar 3. Oksidasi n-alkana melalui jalur sub terminal (Atlas and Bartha, 1992 dalam Nugroho, 2009).

Selain oksidasi terminal, mikroba juga dapat mengoksidasi hidrokarbon alifatik melalui oksidasi subterminal (Gambar 3). Pada jalur ini molekul oksigen dimasukan ke dalam rantai karbon membentuk alkohol sekunder yamg selanjutnya dioksidasi menjadi keton dan akhirnya ester. Kemudian ikatan ester dipecah membentuk alkohol primer dan asam lemak. Selanjutnya alkohol dioksidasi melalui aldehid membentuk asam lemak dan kedua fragmen asam lemak akan dimetabolisme lebih lanjut melalui $\beta$-oksidasi (Atlas and Bartha, 1992 dalam Nugroho, 2009).

Hasil tersebut dipertegas dengan uji anova yang menunjukan bahwa rata-rata $\mathrm{pH}$ diantara keenam perlakuan awal tidak memberikan beda nyata $(P \geq 0,05)$, namun pada akhir perlakuan dari keenam perlakuan menunjukan berbeda nyata $(\mathrm{P} \leq 0,05)$. Dengan demikian, maka pemberian biokompos pada proses degradasi memberikan pengaruh signifikan terhadap nilai $\mathrm{pH}$ keenam perlakuan.

Pada sampel A1, pH mengalami kenaikan yaitu $\mathrm{pH}$ awal sebesar 7,25 dan $\mathrm{pH}$ akhir 7,5. Karena beberapa bakteri memiliki kemampuan untuk melakukan upaya homeostatis terhadap keasaman lingkungan sebatas masih dalam toleransi adaptasinya. Caranya dengan melakukan pertukaran kation 
$\mathrm{K}^{+}$dari dalam sel dan menukarnya dengan $\mathrm{H}^{+}$ yang banyak terdapat di lingkungannya. Akibatnya keasaman lingkungan dapat dikurangi (Chator dan Somerville, 1978 dalam Nugroho, 2006). Hasil penelitian ini sama dengan yang dilakukan oleh Tang et al (2010) bahwa secara umum, perlakuan dengan mikroorganisme dan tanaman dapat menurunkan $\mathrm{pH}$ tanah.

\section{Kadar Air}

Berdasarkan penelitian yang dilakukan, didapatkan hasil analisa kadar air sebagai berikut:

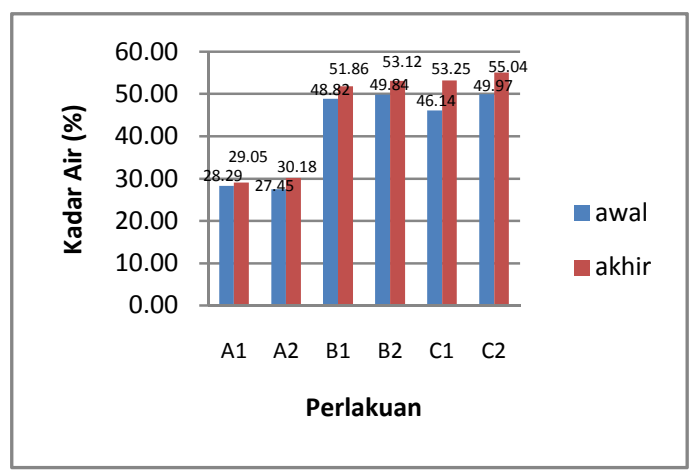

Gambar 4. Hasil analisa kadar air

Kandungan air sangat penting untuk aktivitas metabolik dari mikoba pada limbah minyak bumi karena mikroba akan hidup aktif di interfase antara minyak dan air (Udiharto, 1996). Kelembaban berkisar antara 50-80\% kapasitas penyangga air merupakan kelembaban ideal untuk berlangsungnya aktivitas mikroba (Santosa, 1999).

Melihat data hasil analisis kadar air, sampel A1, A2, B1, B2, C1, C2 mengalami kenaikan. Sampel yang mengalami kenaikanpun berbeda antara sampel yang hanya ditambah inokulan saja, biokompos (kompos + inokulan) dan sampel dengan kompos tanpa inokulan. Begitu juga perbedaan pada komposisi urea yang ditambahkan. Hasil uji anova menunjukan bahwa pemberian biokompos memberikan pengaruh terhadap \% kadar air.

Pada sampel B1 dan C1 mengalami kenaikan kadar air karena sampel tersebut ditambahkan kompos pada perlakuannya. Penambahan bahan organik (kompos) dapat meningkatan porositas tanah. Kondisi ini juga akan berpengaruh pada tingkat aerasi tanah dan status kadar air dalam tanah. Mikroba yang sudah ada dalam kompos dapat memanfaatkan minyak sebagai sumber energi, sehingga molekul-molekul minyak yang melekat pada pori-pori tanah terlepas dan terisi dengan air. Sedangkan perbedaan kadar air antara sampel $\mathrm{B} 1$ dan $\mathrm{C} 1$ dengan $\mathrm{B} 2$ dan $\mathrm{C} 2$ yaitu sampel B2 dan C2 menggunakan kompos + inokulan, sehingga kadar air dari sampel B2 dan C2 lebih besar daripada sampel B1 dan $\mathrm{C} 1$. Hal ini disebabkan adanya inokulan yang ditambahkan dari hasil isolasi terpilih. Penambahan hasil isolate terpilih ini menyebabkan mikroba lebih cepat mendegradasi minyak, karena adaptasi yang baik. Akibatnya pertumbuhan rumput gajah pun mengalami kenaikan yang diperlihatkan dengan makin panjangnya daun

Sampel A1 dan A2 merupakan kontrol, namun A2 memiliki perbedaan kadar air yang lebih besar dari A1 yaitu A2 sebesar $30,18 \%$ dan A1 sebesar 29,05\%. Hal ini disebabkan sampel A2 ditambah inokulan sedangkan sampel A1 tidak. Inokulan tersebut dapat mendegradasi minyak lebih cepat, dan molekul airpun dapat terjerap dalam pori-pori tanah.

\section{Kemampuan Ikat Air/Water Holding Capacity (WHC).}

Kemampuan ikat air didefinisikan sebagai kemampuan suatu bahan untuk menyerap dan menahan air. Hasil analisis WHC sampel dapat dilihat dari gambar berikut.

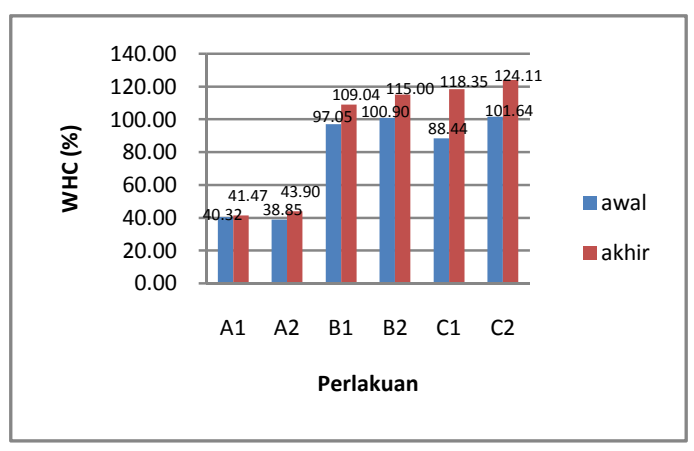

Gambar 5. Hasil analisa water holding capacity (WHC)

Berdasarkan gambar 5 nilai WHC akhir secara berurutan pada sampel A1, A2, B1, B2, C1, dan C2 adalah 41,47\%, 43,90\%, $109,04 \%, 115 \%, 118,35 \%$, dan $124,11 \%$. Perbedaan nilai WHC tersebut sangat 
dipengaruhi oleh penambahan biokompos dan urea.

Secara umum pemberian biokompos memberikan pengaruh yang signifikan terhadap \% WHC. Hal ini karena biokompos mengandung mikroorganisme pendegradasi minyak bumi. Pada sampel A1 mengalami kenaikan lebih kecil dibandingkan dengan A2. Hal ini disebabkan sampel A1 merupakan kontrol yang hanya ditanami dengan rumput gajah dan tanpa inokulan. Rumput gajah dan mikroba indigen tidak mampu mendegradasi senyawa organik secara cepat yang terdapat dalam tanah. Minyak bumi menyelimuti tanah dan masuk ke dalam pori-pori tanah sehingga air tidak dapat terjerap oleh tanah karena air bersifat polar sedangkan minyak bersifat nonpolar. Adanya perbedaan sifat ini menyebabkan air tidak akan terjerap oleh tanah yang sudah dipenuhi dengan minyak.

Sampel A2 mengalami kenaikan nilai WHC, karena pada sampel A2 ditambah inokulan mikroba pendegradasi minyak bumi. Keberadaan mikroba ini dapat mendegradasi minyak dalam tanah, karena minyak tersebut dapat difungsikan sebagai sumber energi mikroba. Bahan utama minyak bumi adalah hidrokarbon alifatik dan aromatik, yaitu senyawa-senyawa organik di mana setiap molekulnya hanya mempunyai unsur karbon dan hidrogen saja.

Biodegradasi hidrokarbon alifatik biasanya terjadi pada kondisi aerob. Tahap awal degradasi hidrokarbon secara aerob adalah memasukkan molekul oksigen ke dalam hidrokarbon oleh enzim oksigenase (Nugroho, 2009). Menurut R.M. Atlas, and R. Bartha (1992) dalam Nugroho (2009) Jalur degradasi alkana yang paling umum adalah oksidasi rantai terminal (Gambar 4.5). Alkana dioksidasi menjadi alkohol dan selanjutnya menjadi asam lemak (Cookson, 1995 dalam Nugroho, 2009).

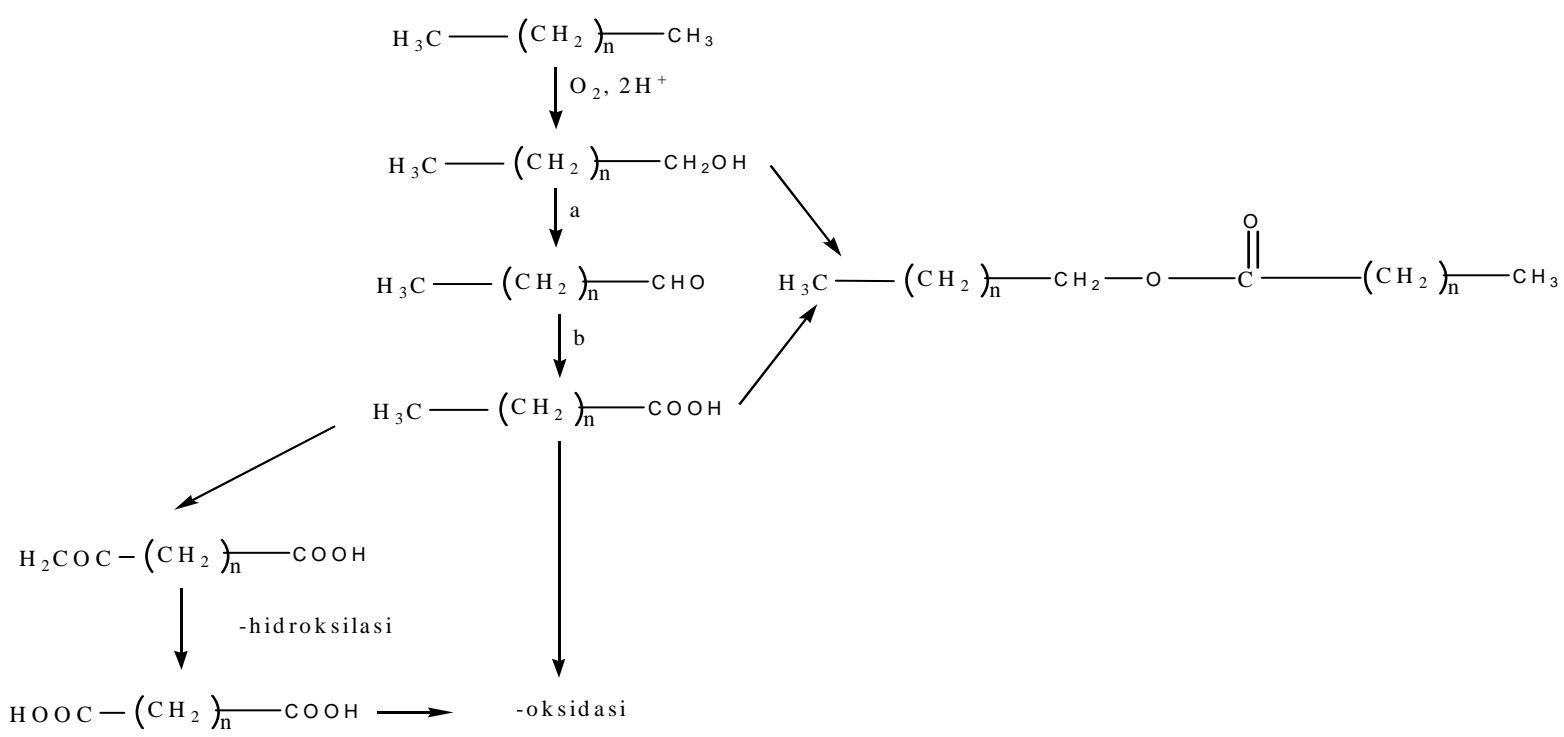

Gambar 6. Oksidasi n-alkana melalui Jalur Terminal: a. Monooksigenase; b. Alkoholdehidrogenase; c. Aldehid dehidrogenase (Cookson, 1995 dalam Nugroho, 2009).

Sampel B1, B2, C1, dan C2 mengalami kenaikan nilai WHC, ini karena sampel tersebut menggunakan kompos dan biokompos sebagai bahan organik. Pengaruh bahan organik terhadap sifat fisika tanah yang lain adalah terhadap peningkatan porositas tanah. Porositas tanah adalah ukuran yang menunjukkan bagian tanah yang tidak terisi bahan padat tanah yang terisi oleh udara dan air (Stevenson, 1982). Menurut Mashur, 2001, vermikompos mempunyai kemampuan menahan air sebesar 40-60\%. Hal ini karena struktur vermikompos yang memiliki ruangruang yang mampu menyerap dan menyimpan air, sehingga mampu mempertahankan kelembaban.

Terdapat perbedaan hasil kenaikan nilai WHC antara sampel B1, C1 dan B2, C2 yaitu karena sampel B1, C1 tanpa inokulan, sedangkan sampel B2, C2 menggunakan inokulan dan perbedaan komposisi urea, sehingga antara mikroba inokulan dengan 
mikroba yang sudah ada divermikompos sinergis, dan banyaknya unsur $\mathrm{N}$ dalam tanah, akan dimanfaatkan oleh mikroba untuk metabolismenya, sehingga untuk mendegradasi polutan minyakpun lebih cepat.

Kenaikan nilai WHC pada perlakuan menandakan terjadinya kemampuan dalam mengikat uap air. Hal ini sekaligus menunjukkan bahwa ikatan antara vermikompos dan limbah lumpur minyak bumi dalam sampel mulai digantikan oleh air. Pergantian ini mengindikasikan terjadinya degradasi limbah lumpur menjadi senyawasenyawa lain. Disamping itu menunjukkan pula bahwa dalam proses fermentasi mikroba terjadi degradasi limbah lumpur minyak bumi.

\section{Kadar Abu}

Abu adalah zat anorganik sisa hasil pembakaran suatu bahan organik, kadar abu suatu bahan tergantung bahan dan cara pengabuannya (Sudarmadji et al., 1996). Data gambar 4.6, menunjukan terjadi perubahan kadar abu yang nyata antara keadaan sebelum dan setelah fermentasi degradatif dari limbah lumpur minyak bumi. Hasil statistik anova menunjukan bahwa kadar abu di antara keenam perlakuan berbeda nyata $(\mathrm{P} \leq 0,05)$, ini menunjukan bahwa pemberian biokompos memberikan pengaruh yang signifikan berupa peningkatan kadar abu di akhir perlakuan.

Berdasarkan penelitian yang telah dilakukan, didapatkan hasil seperti yang ditunjukkan dalam gambar berikut ini:

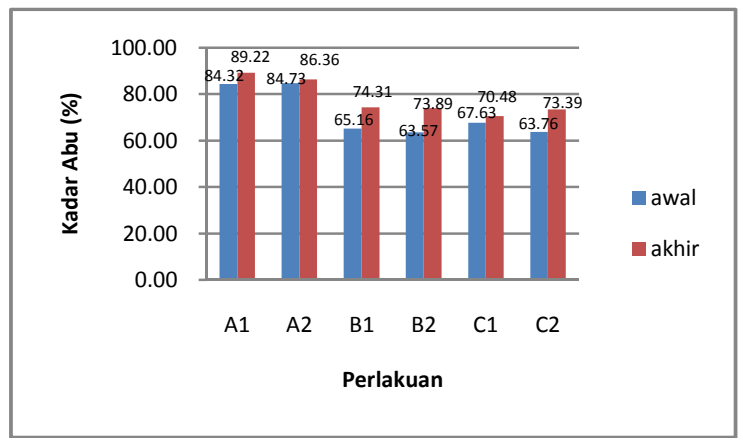

Gambar 7. Hasil analisa kadar abu

Secara keseluruhan keenam perlakuan (A1, A2, B1, B2, C1, dan C2) mengalami kenaikan kadar abu. Hal tersebut disebabkan bahan yang terkandung dalam perlakuan terjadi proses mineralisasi. Proses mineralisasi ini diakibatkan oleh metabolisme dari tanaman dan mikrobanya, dengan cara memanfaatkan polutan yang terkandung dalam media. Mineral tersebut terdapat dalam bentuk garam organik, garam anorganik, atau sebagai bentuk senyawa kompleks yang bersifat organis (Muljohardjo, 1988).

Tanaman melepaskan eskudat di rizosfer kemungkinan untuk kebutuhan sebagai sumber karbon untuk mikroba (Bowen and Rovira, 1991 dalam Nwoko, 2010). Eskudat yang dikeluarkan berupa gula, pati, dan asamasam organik yang dapat dimanfaatkan oleh mikroba sebagai sumber karbon. Akibatnya, mikroba rizosfer dapat meningkatkan kesehatan tanaman dengan menstimulasi pertumbuhan akar melalui produksi pengatur pertumbuhan tanaman, meningkatkan penyerapan mineral dan air (Nwoko, 2010). Tanaman merangsang seluruh proses dengan terlebih dahulu, melepaskan senyawa karbon untuk memfasilitasi populasi mikroba yang lebih tinggi disekitar daerah akar. Kedua, tanaman melepaskan senyawa yang dari akar khusus yang dapat menyebabkan gen mikroba yang terlibat dalam degradasi atau bertindak sebagai co-metabolit untuk memfasilitasi degradasi mikroba (Olson et al., 2003. Leigh et al., 2002 dalam Nwoko, 2010).

\section{Persen Degradasi Total Petroleum Hidrokarbon (TPH) dan Biomassa Rumput Gajah.}

Berdasarkan hasil analisa, maka didapatkan hasil seperti yang ditunjukan dalam tabel berikut ini:

Tabel 2. Hasil analisa total petroleum hidrokarbon.

\begin{tabular}{|c|c|c|c|c|}
\hline \multirow[t]{2}{*}{ No } & \multirow[t]{2}{*}{$\begin{array}{l}\text { Samp } \\
\text { el }\end{array}$} & \multicolumn{2}{|c|}{$\begin{array}{l}\text { Total Petroleum } \\
\text { Hidrokarbon } \\
\text { (TPH) }\end{array}$} & \multirow[t]{2}{*}{$\begin{array}{c}\text { \% Degradasi } \\
\text { TPH }\end{array}$} \\
\hline & & $\mathrm{H}-0$ & H-35 & \\
\hline 1 & A1 & 0.0694 & $\begin{array}{c}0.055 \\
2 \\
\end{array}$ & 20.48 \\
\hline 2 & A2 & 0.0618 & $\begin{array}{c}0.044 \\
8 \\
\end{array}$ & 27.55 \\
\hline 3 & B1 & 0.0199 & $\begin{array}{c}0.007 \\
1\end{array}$ & 64.38 \\
\hline 4 & B2 & 0.0205 & $\begin{array}{c}0.003 \\
6\end{array}$ & 82.44 \\
\hline 5 & $\mathrm{C} 1$ & 0.0277 & $\begin{array}{c}0.014 \\
7\end{array}$ & 47.03 \\
\hline 6 & $\mathrm{C} 2$ & 0.0294 & $\begin{array}{c}0.002 \\
6\end{array}$ & 91.15 \\
\hline
\end{tabular}


Tabel 3. Biomassa Rumput Gajah

\begin{tabular}{|c|c|}
\hline Perlakuan & Bobot daun $(\mathrm{g})$ \\
\hline $\mathrm{A} 1$ & $2,12 \pm 0,481$ \\
\hline $\mathrm{A} 2$ & $1.93 \pm 0,997$ \\
\hline $\mathrm{B} 1$ & $36,43 \pm 2,448$ \\
\hline $\mathrm{B} 2$ & $12,82 \pm 13,346^{*}$ \\
\hline $\mathrm{C} 1$ & $39,02 \pm 55,177^{*}$ \\
\hline $\mathrm{C} 2$ & $2,16 \pm 1,250$ \\
\hline
\end{tabular}

Keterangan : (*) rumput gajah ada yang mengalami kematian.

Metode yang dilakukan pada analisa ini didasarkan pada perbedaan bobot kering kontrol dan sampel yang diekstrak dengan nheksan. Selisih perbedaan bobot kering tersebut disimpulkan sebagai total senyawa hidrokarbon yang terdapat dalam sampel. Berdasarkan hasil analisa TPH diatas, penurunan TPH terbesar terjadi pada sampel C2 (100 g berat kering lumpur minyak bumi, $100 \mathrm{~g}$ berat kering biokompos + inokulan, $9 \mathrm{~g}$ urea, rasio $\mathrm{C} / \mathrm{N}=5$ ) dengan nilai penurunan 91.15\% diikuti oleh sampel B2 (100 g berat kering lumpur minyak bumi, $100 \mathrm{~g}$ berat kering biokompos + inokulan, $2 \mathrm{~g}$ urea, rasio $\mathrm{C} / \mathrm{N}=10)$ dengan $82.44 \%$ kemudian sampel B1 (100 g berat kering lumpur minyak bumi, $100 \mathrm{~g}$ berat kering biokompos, $2 \mathrm{~g}$ urea, rasio $\mathrm{C} / \mathrm{N}=10), \mathrm{C} 1$ (100 g berat kering lumpur minyak bumi, $100 \mathrm{~g}$ berat kering biokompos, 9 $\mathrm{g}$ urea, rasio $\mathrm{C} / \mathrm{N}=5$ ), A2 (200 g berat kering + inokulan, rasio $\mathrm{C} / \mathrm{N}=15)$, dan $\mathrm{A} 1(200 \mathrm{~g}$ berat kering, rasio $\mathrm{C} / \mathrm{N}=15$ ) yang masingmasing nilai penurunannya $64.38 \%, 47.03 \%$, $27.55 \%$, dan $20.48 \%$. Dari data tersebut terdapat perbedaan persen degradasi TPH pada setiap parameter. Pada sampel C2 (dengan inokulan) lebih besar dibandingkan dengan sampel C1 (tanpa inokulan), disebabkan adanya inokulan degradasi TPH lebih cepat. Karena mikroba diinokulan lebih terbiasa pada media minyak bumi. Begitu pula pada sampel B2 (dengan inokulan) lebih besar dari pada B1 (tanpa inokulan) dan sampel A2 (dengan inokulan) lebih besar dari pada A1 (tanpa inokulan). Adapun hasil degradasi sampel yang berbeda pada sampel C2 dengan B2 disebabkan perbedaan perlakuan pada komposisi urea, yang mana $\mathrm{C} 2$ komposisi ureanya lebih besar dari pada B2. Komposisi urea yang lebih besar dapat mempercepat proses metabolisme mikroorganisme, sehingga proses degradasi lebih cepat.

Urea merupakan sumber nitrogen yang murah dan mudah tersedia bagi mikroba. Nitrogen merupakan suatu keharusan bagi biosintesis asam amino dan basa purin serta pirimidin, yang merupakan unit pembangun protein dan asam nukleat bernitrogen (Lehninger,1994). Urea yang dimasukkan ke dalam tanah akan mengalami proses amonifikasi sebagai berikut:

$$
\mathrm{CO}\left(\mathrm{NH}_{2}\right)_{2}+\mathrm{H}_{2} \mathrm{O} \stackrel{\text { urease }}{\longrightarrow} 2 \mathrm{NH}_{3}+\mathrm{CO}_{2}
$$

Dalam keadaan asam dan netral amonia berada sebagai ion amonium. Ion amonium dapat diasimilasi tanaman dan mikroba, selanjutnya diubah menjadi asam amino atau senyawa $\mathrm{N}$ lain. Di dalam sel, ammonia direaksikan oleh glutamat atau glutamin sintase atau mengalami proses aminasi langsung dengan asam-ketokarboksilat sehingga berubah menjadi asam amino (Sumarsih, 2003). Selanjutnya asam amino membentuk ikatan-ikatan peptida dengan asam amino yang lain membentuk protein. Protein ini dibutuhkan untuk perkembangbiakan mikroba, dengan banyaknya urea yang ditambahkan proses perkembangbiakan semakin cepat, dan proses degradasipun lebih cepat.

Secara statistik Anova pemberian biokompos dan rumput gajah memberikan pengaruh signifikan \% degradasi minyak bumi. Hal ini karena kedua aktivitas mikroba dan pertumbuhan tanaman dapat dipengaruhi oleh penambahan pupuk, penambahan pupuk merupakan faktor penting dalam mempengaruhi efisiensi proses bioremediasi. Tabel 4.1 menunjukkan tingkat degradasi TPH dengan tingkat penambahan urea yang berbeda. Hubungan positif antara tingkat degradasi TPH dan tingkat penambahan pupuk urea menunjukkan efektif dalam meningkatkan proses rhizoremediasi TPH. Di sisi lain menunjukan perubahan berat biomassa dengan penambahan urea dengan jumlah yang berbeda dan penambahan inokulan. Berdasarkan aplikasi urea $2 \mathrm{~g}$, biomassa rumput gajah meningkat dengan penambahan urea yaitu $36,43 \pm 2,448 \mathrm{~g}$ seperti terlihat pada perlakuan B1(tanpa inokulan). Dengan aplikasi yang sama dan penambahan inokulan, biomassa rumput gajah menurun dengan penambahan 
urea yaitu $12,82 \pm 13,346$ g pada perlakuan B2. Namun, berat biomassa yang rendah ditemukan dengan tingkat aplikasi urea yang lebih tinggi $9 \mathrm{~g}$, dengan nilai biomassa sebesar $2,16 \pm 1,250 \mathrm{~g}$ yaitu perlakuan $\mathrm{C} 2$ (dengan inokulan). Sedangkan dengan perlakuan yang sama perlakuan $\mathrm{C} 1$ (tanpa inokulan) mengalami peningkatan nilai biomassa sebesar $39,02 \pm 55,177 \mathrm{~g}$.

Sedangkan perbedaan nilai biomassa pada perlakuan yang ditambahkan inokulan dan tanpa inokulan. Pada perlakuan B2 dan C2 yang ditambahkan inokulan mengalami penurunan nilai biomassa sebesar 12,82 \pm $13,346 \mathrm{~g}$ dan $2,16 \pm 1,250 \mathrm{~g}$. Pada perlakuan B1 dan $\mathrm{C} 1$ mengalami kenaikan nilai biomassa sebesar 36,43 $\pm 2,448 \mathrm{~g}$ dan 39,02 $\pm 55,177 \mathrm{~g}$. Hal ini disebabkan karena pada perlakuan yang ditambahkan inokulan, terjadi kompetisi antara inokulan dengan rumput gajah dalam mengambil unsur-unsur hara yang terdapat pada media untuk kebutuhan metabolisme. Sehingga pertumbuhan rumput gajah menjadi terhambat dan bahkan mengalami kematian. Sedangkan perlakuan tanpa inokulan dengan adanya pemberian kompos dan urea saja sudah cukup untuk kebutuhan metabolisme mikroorganisme dan rumput gajah, sehingga pertumbuhan biomassanya tidak terganggu.

Penambahan inokulan degradasi minyak lebih cepat, tapi hasil degradasi diantaranya senyawa fenol yang merupakan zat toksik untuk pertumbuhan tanaman. Karena senyawa fenol memiliki beberapa sifat diantaranya mudah larut dalam air, senyawa fenol yang terlarut berpengaruh terhadap proses perakaran, tergantung pada konsentrasinya. Proses penyerapan senyawa fenol terhadap akar sama halnya terjadi pada perkecambahan. Menurut Salisbury and Ross (1992); Colton and Einhellig (1980) dalam Tambaru, E dan Santosa (1999) Konsentrasi senyawa fenol dalam air yang tinggi dapat menaikan potensial osmotik, sehingga dapat menghambat difusi air dan $\mathrm{O}_{2}$ ke dalam kecambah. Jika air yang dibutuhkan tidak terpenuhi, maka hal ini dapat menghambat sintesis hormon IAA, GA, dan sitokini, sehingga perkecambahan dan pertumbuhan kecambah terhambat (Santosa, 1990; Rice, 1984 dalam Tambaru, E dan Santosa, 1999 ). Berkurangnya difusi air ke dalam biji juga mempengaruhi transport $\mathrm{O}_{2}, \quad$ sehingga menghambat proses respirasi dan ATP yang dihasilkan terbatas. ATP sangat dibutuhkan untuk perkecambahan dan pertumbuhan kecambah (Salisbury dan Ross, 1992 dalam Tambaru, E dan Santosa, 1999).

Menurut Salt et al (1998), Beberapa bahan kimia dimineralisasi oleh tanaman dengan bantuan air dan $\mathrm{CO}_{2}$. Tanaman mengeluarkan sekret melalui eksudat akar sebesar 10 - 20\% dari hasil fotosintesis melalui eksudat akar. Hal ini dapat membantu proses pertumbuhan dan metabolisme mikroba maupun fungi yang hidup disekitar rizosfer. Beberapa senyawa organik yang dikeluarkan melalui eksudat akar (misalnya fenolik, asam organik, alkohol, protein ) dapat menjadi sumber karbon dan nitrogen sebagai sumber pertumbuhan mikroba yang dapat membantu proses degradasi senyawa organik. Sekret berupa senyawa organik dapat membantu pertumbuhan dan meningkatkan aktivitas mikroba rizosfer. Adapun reaksi pembentukan senyawa fenolik dari hasil degradasi adalah sebagai berikut (Gambar 8 ). 


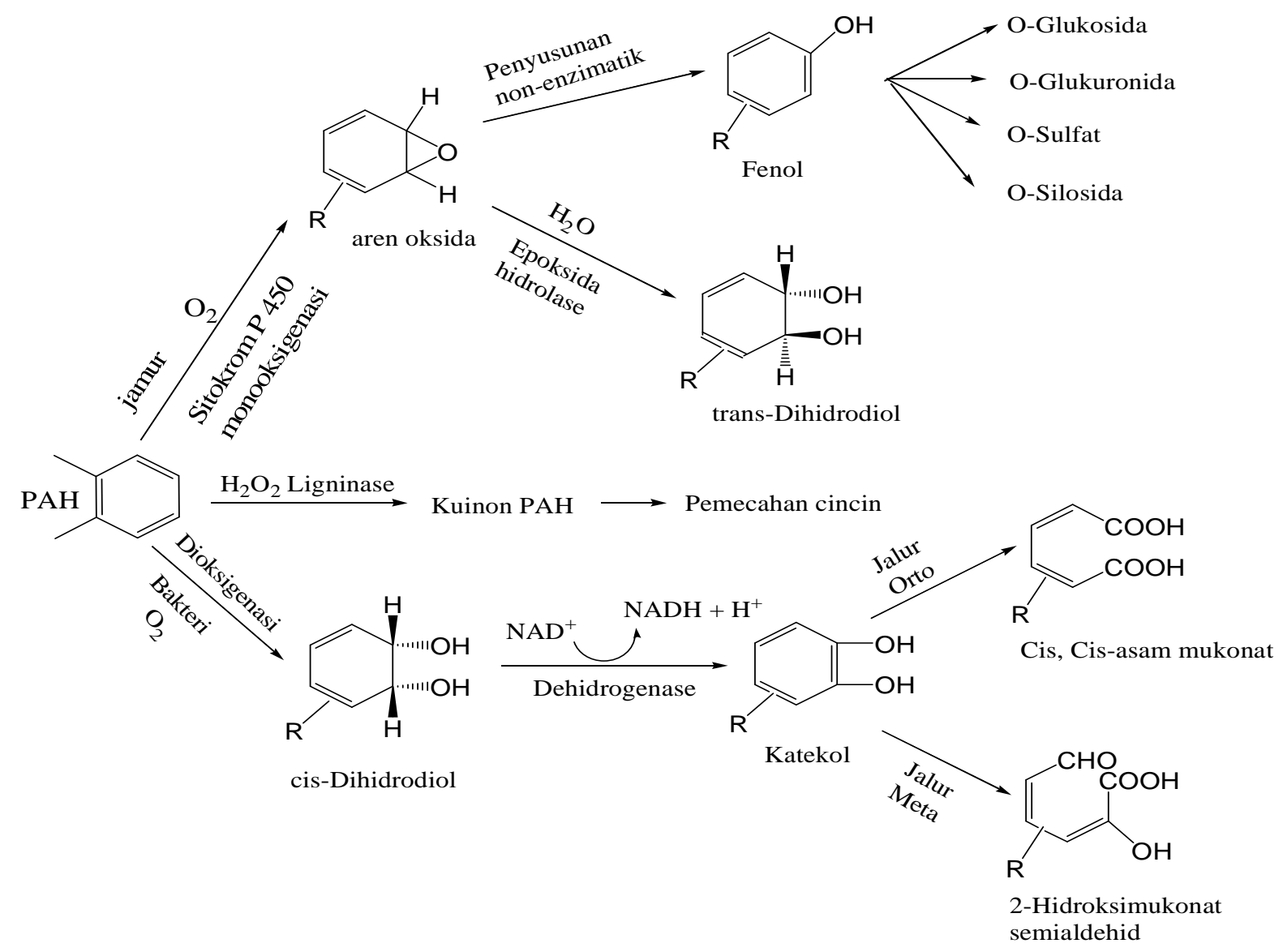

Gambar 8 Reaksi degradasi senyawa hidrokarbon polisiklik aromatik (PAH) (Cerniglia, 1992)

Terdapat tiga cara transport hidrokarbon ke dalam sel bakteri secara umum yaitu (Wulandari et al., 2010):

1. Interasksi sel dengan hidrokarbon yang terlarut dalam fase air, umumnya rata-rata kelarutan hidrokarbon oleh proses fisika sangat rendah sehingga tidak dapat mendukung.

2. Kontak langsung (perlekatan) sel dengan permukaan tetesan hidrokarbon yang lebih besar daripada sel mikroba. Pada kasus yang kedua ini, perlekatan dapat terjadi karena sel bakteri bersifat hidrofobik. Sel mikroba melekat pada permukaan tetesan hidrokarbon yang lebih besar daripada sel dan pengambilan substrat dilakukan dengan difusi atau transport aktif. Perlekatan ini terjadi karena adanya biosurfaktan pada membrane sel bakteri.

3. Interaksi sel dengan tetesan hidrokarbon yang telah teremulsi atau tersolubilisasi oleh bakteri. Pada kasus ini sel mikroba berinteraksi dengan partikel hidrokarbon yang lebih kecil daripada sel. Hidrokarbon dapat teremulsi dan tersolubilisasi dengan adanya biosurfaktan yang dilepaskan oleh bakteri ke dalam medium.

Menurut Mc Cutcheon dan Schnoor (2003); Nwoko et al (2007) dalan Nwoko (2010) tanaman dapat meningkatkan biodegradasi polutan organik oleh mikroba dalam rizosfer tanaman (fitostimulasi atau rizodegradasi). Tanaman juga dapat menurunkan polutan organik secara langsung melalui kegiatan enzimatik mereka sendiri yang

disebut fitodegradasi (Nwoko et al., 2007 dalam Nwoko 2010). Menurut Terry et al (1995) dalam Nwoko (2010) juga bahwa beberapa polutan juga dapat tertinggal ditanaman dalam bentuk yang mudah menguap (fitostabilisasi).

Remediasi mikroba dapat meningkatkan nilai degradasi TPH lebih efektif dengan peningkatan sebesar 91,15\% pada perlakuan $\mathrm{C} 2$ dibandingkan dengan 
blanko (A1 dan A2 masing-masing sebesar $20,48 \%$, dan 27,55 \%). Tabel 4 menunjukan fitoremediasi biomassa yang dihasilkan berturut-turut pada sampel A1, A2, B1, B2, $\mathrm{C} 1$, dan $\mathrm{C} 2$ adalah $2,12 \pm 0,481 \mathrm{~g} ; 1.93 \pm$ $0,997 \mathrm{~g} ; 36,43 \pm 2,448 \mathrm{~g} ; 12,82 \pm 13,346 \mathrm{~g}$; $39,02 \pm 55,177 \mathrm{~g}$; dan $2,16 \pm 1,250 \mathrm{~g}$.

Faktor lain yang mempengaruhi proses rizoremediasi mencakup inokulasi, penambahan nutrisi, kadar organik tanah, kedalaman tanah dan kadar garam dan sebagainya (Mishra et al., 2001; Margesin et al., 2003;. Lin and Mendelssohn, 1998; Hutchinson et al., 2001; Keller et al., 2008 dalam Tang, et al., 2010).

\section{KESIMPULAN DAN SARAN}

\section{Kesimpulan}

Berdasarkan hasil penelitian multi fungsi biokompos dalam rehabilitasi lahan tercemar limbah lumpur minyak bumi dapat disimpulkan sebagai berikut:

1. Penambahan kompos dan urea dapat meningkatkan efisiensi degradasi TPH dan diperoleh hubungan positif antara jumlah penambahan kompos dan urea terhadap tingkat degradasi TPH.

2. Komposisi medium terbaik dalam mendegradasi TPH adalah perlakuan $\mathrm{C} 2$ (100 g berat kering lumpur minyak bumi, $100 \mathrm{~g}$ berat kering biokompos, $9 \mathrm{~g}$ urea, rasio $\mathrm{C} / \mathrm{N}=5$ ) dengan tingkat degradasi $91,15 \%$,

3. Faktor lingkungan yang menghasilkan kondisi optimal ini dicapai pada remediasi diperoleh melalui kondisi awal $\mathrm{pH} 8,25$; kadar air 49,97\%; WHC 101,64\%; dan kadar abu $63,76 \%$ dan kondisi akhir $\mathrm{pH}$ 6,25; kadar air 55,04\%; kadar abu 73,39\%; dan WHC $124,11 \%$.

\section{Saran}

Pada penelitian ini masih diperlukan penelitian lanjutan, yaitu:

1. Perlu adanya justifikasi fenol hasil degradasi TPH yang telah hilang sebelum proses fitoremediasi. Sehingga ketika aplikasi fitoremediasi dengan tanaman tidak mudah mengalami kematian dan proses degradasi polutan minyak lebih optimal.
2. Perlu pengujian lanjutan secara kuantitatif terhadap pengaruh penambahan biokompos, urea, inokulan pada rasio $\mathrm{C} / \mathrm{N}$ yang sama.

\section{DAFTAR PUSTAKA}

1. Ahn. H.K. T.j.Sauer. T.L. Richard. and T.D.Glanville. 2009. Determination of Thermal Properties of Composting Bulking Materials. Bioresourece Technology 100 (2009): 39743981.

2. Ambriyanto. K.S, 2010. Isolasi Dan Karakterisasi Bakteri Aerob Pendegradasi Selulosa Dari Serasah Daun Rumput Gajah (pennisetum purpureum schaum). Skripsi. ITS. Surabaya.

3. Cerniglia, C.E. 1992. Biodegradation of Polycycluc Aromatic Hydrocarbons, In: Biodegradation journal, vol 3. Kluwer Academic Pub. Netherlands. p 351-368.

4. Gunalan. 1996. Penerapan Bioremediasi pada Pengelohan Limbah dan Pemulihan LingkunganTercemar Hidrokarbon Petroleum. Majalah Sriwijaya. UNSRI. Vol 32, No 1.

5. Karwati. 2009. Degradasi Hidrokarbon Pada Tanah Tercemari Minyak Bumi Dengan Isolat A10 Dan D8. Skripsi. IPB. Bogor.

6. Lehninger, A.L. 1994. Dasar-dasar Biokimia, alih bahasa oleh Maggy Thenawidjaja. Erlangga. Jakarta.

7. Mashur. 2001. Vermikompos (kompos cacing tanah) Pupuk Organik Berkualitas dan Ramah Lingkungan. Instalasi Penelitian dan Pengkajian Teknologi Pertanian (IPPTP) Mataram Badan Penelitian dan Pengembangan Pertanian, Mataram.

8. Muljohardjo. 1988. Teknologi Pengawetan Pangan. U.I. Press. Jakarta.

9. Natural Resources Conservation Service (NRCS), 2000, Chapter 2 Composting, National Enginereing Handbook, Part 637 Environmental Engineering, Natural Resources Conservation Service - United States Department of Agriculture, Pages 29-35

10. Nghia. N. K. 2007. Degradation of Aged Creosote and Diesel Contaminated Soils by Phytoremediation or Biostimulation (nutrients). MASTER THESIS in Soil Science, 20 credits. Sveriges lantbruksuniversitet.

11. Nugroho, A. 2009. Produksi Gas Hasil Biodegradasi Minyak Bumi: Kajian Awal Aplikasinya dalam Microbial Enhanced Oil Recovery (MEOR). Makara, Sains. Vol 13. No.2. 111-116.

12. Nugroho, A. 2006. Biodegradasi 'Sludge' Minyak Bumi Dalam Skala Mikrokosmos. Makara Teknologi. 10 (2): 82-89.

13. Nwoko. Chris O. 2010. Trends in phytoremediation of toxic elemental and 
organic pollutants. African Journal of Biotechnology. Vol. 9 (37), pp. 6010-6016.

14. Salt, D.E., R.D. Smith and I. Raskin. 1998. Annual Review Plant Physiology and Plant Molecular Biology : Phytoremediation. Annual Reviews. USA. 501-662.

15. Santosa.D.A. 1999. Bahan kuliah Bioteknologi Tanah. Jurusan Tanah. Fakultas Pertanian. Institute Pertanian Bogor.

16. SEAMEO BIOTROP. 2011. Services Laboratory Pengukuran pH Tanah. Diakses dari http:www.biotrop.org.

17. Stevenson, F.T. 1982. Humus Chemistry. John Wiley and Sons, Newyork

18. Sudarmadji, S, Bambang, H dan Suhardi. 1996. Analisa Bahan Makan dan Pertanian. Liberty. Yogyakarta.

19. Sugoro, I. 2002. Bioremediasi 'Sludge' Limbah Minyak Bumi Lahan Tercemar Dengan Teknik 'Land Farming' Dalam Skala Laboratorium. Tesis Megister. ITB: Bandung.

20. Sumarsih, S. 2003. Diktat Kuliah. Mikrobiologi Dasar. UPN. Yogyakarta.

21. Tambaru. E. S. 1999. Pengaruh Hasil Dekomposisi Seresah Mahoni (Swietenia macrophylla King) Terhadap Perkecambahan Biji, Infeksi Mikoriza Vesikular-Arbuskular dan Pertumbuhan Bibit Akasia ( Acacia Mangium Willd). Tesis. UGM. Jogjakarta.

22. Tang. J, R. Wang, X. Niu, M. Wang, and Q. Zhou. 2010. Characterization on the rhizoremediation of petroleum contaminated soil as affected by different influencing factors. Biogeosciences Discuss., 7, 4665-4688.

23. Tang, J. Xiaowei, N. Qing, S. Rugang Wang. 2010. Bioremediation of Petroleum Polluted Soil by Combination of Ryegrass with Effective Microorganisms. Journal of Environmental Technology and Engineering, 3(2):80-86.

24. Udiharto, M., S. A. Rahayu, A. Haris dan Zulkifliani. 1995. Peran bakteri dalam degradasi minyak dan pemanfaatannya dalam penanggulangan minyak bumi buangan.Proceedings Diskusi Ilmiah VIII PPTMGB.Lemigas, Jakarta.

25. Wulandari, A. Arif, W. Khusnul. Nevy, Y.P. Rena, T.H. Sofiyah, K.B. Sri, L.D. 2010. Tugas Terstruktur Bkateriologi. Bioremediasi Minyak Bumi Oleh Bakteri pseudomonas sp. Kementrian Pendidikan Nasional. Univ. Jendral Sudirman. Purwokerto.

26. Zyomuya, F., F.J. Larney, C.K. Nichol, A.F. Olson, J.J. Miller, and P.R. Demare. 2005. Chemical and Physical Changes Following CoComposting of Beef Cattle Feedlot Manure with Phosphogypsum. J. Environ. Qual. 34:23172318. 